\title{
Anaemia of rheumatoid arthritis: serum erythropoietin concentrations and red cell distribution width in relation to iron status
}

Ove Juul Nielsen, Lis Smedegaard Andersen, Erik Ludwigsen, Pierre Bouchelouche, Troels Mørk Hansen, Henrik Birgens, Niels Ebbe Hansen

The mean serum erythropoietin level $(57.6$ (SD) $27 \cdot 3$ ) $\mathrm{U} / \mathrm{l}$ ) was sufficiently raised for the degree of anaemia irrespective of the size of the marrow iron stores. Thus the data do not support the contention that suppressed secretion of erythropoietin is involved in the pathogenesis of anaemia of chronic disorders.

There was a significant inverse correlation between the haemoglobin concentration and log serum erythropoietin in the patients with rheumatoid arthritis.

In the patients with adequate iron stores, but not in the iron depleted patients, there was a tendency for serum erythropoietin concentrations to correlate positively both with $\mathbf{C}$ reactive protein and erythrocyte sedimentation rate.

Red cell distribution width (mean (SD) $16 \cdot 3$ $(1.8) \%)$ was above normal $(11 \cdot 5-14.5 \%)$ both in the iron replete and the iron depleted patients, and the mean red cell distribution width values did not differ significantly among the two subpopulations.

The plasma lactoferrin concentration (mean (SD) 137.6 (109.9) $\mu \mathrm{g} / \mathrm{l}$ ) was normal and did not differ significantly between the iron deficient patients and those with adequate

Hospital, 6300 Graasten, deficien
Denmark

L S Andersen

T M Hansen

Department of Pathology Sønderborg Hospital, 6400 Sønderborg,

Denmark

E Ludwigsen

Department of Clinical

Chemistry,

Herlev University

Hospital, 4300 Herlev,

Denmark
$P$ Bouchelouche

Correspondence to:

Dr Ove Juul Nielsen,

Medical Department $P$

Division of Nephrology,

Rigshospitalet,

Blegdamsvej 9, DK-2100

Copenhagen $\emptyset$, Denmark

Accepted for publication

12 June 1989

The pathogenesis of the anaemia of chronic disorders, which regularly accompanies active rheumatoid arthritis, is still largely unknown. ${ }^{1}$

In patients with rheumatoid arthritis stereotypic disturbances of iron metabolism are found, accumulation of iron in the macrophages. This reticuloendothelial iron blockade may critically deprive the bone marrow of an adequate iron supply. ${ }^{2}$ On the other hand, marrow erythropoiesis seems to be suppressed by unknown inhibitory mechanisms, which are independent of the compromised iron supply. ${ }^{3}$

The possible involvement of insufficient

\begin{abstract}
Immunoreactive serum erythropoietin concentrations were measured in $\mathbf{3 5}$ patients with anaemia associated with active rheumatoid arthritis.

Based on an evaluation of stainable iron in the bone marrow (marrow iron grade $0-4$ ) and serum ferritin concentrations (concentrations $\leqslant 60 \mu \mathrm{g} / \mathrm{l}$ compatible with iron deficiency) the anaemia was found to be complicated by iron deficiency in $19 / 35(54 \%)$ of the patients.
\end{abstract}

chronic disorders has recently been explored in different studies; conflicting results have been obtained. Both Baer $e t a l^{4}$ and Hochberg $e t a l^{5}$ concluded that serum erythropoietin concentrations were insufficiently low for the degree of anaemia, whereas Cotes ${ }^{6}$ and Birgegaard et $a l^{7}$ measured serum erythropoietin concentrations which were appropriate to the anaemic stimulus.

The clinical implications of defining the pathophysiological role of erythropoietin in anaemia of chronic disorders have recently been accentuated by the option of treating anaemia related to erythropoietin deficiency with recombinant human erythropoietin. ${ }^{8}$

It has been reported that recombinant human erythropoietin efficiently induces an increase in red cell mass in anaemic patients with active rheumatoid arthritis, even though fairly high doses of erythropoietin are required. ${ }^{9}$ The somewhat blunted but consistently favourable erythropoietic response to recombinant human erythropoietin in these patients, however, does not necessarily imply that deficient erythropoietin release is involved in the development of anaemia of chronic disorders. (In normal mice excessive doses of recombinant human erythropoietin cause polycythaemia.)

This study was undertaken to re-evaluate the adequacy of the secretory erythropoietin response in the anaemia of chronic disorders associated with active rheumatoid arthritis. Serum erythropoietin concentrations were systematically related to haemoglobin concentrations, the iron status, and to the inflammatory activity of each individual patient.

Another important aim of the investigation was to explore the diagnostic value of serum erythropoietin concentrations, serum ferritin measurements, plasma lactoferrin values, and analysis of red cell distribution width in distinguishing between the absence and presence of iron in anaemic patients with active rheumatoid arthritis. which include hypoferraemia and a universal production of erythropoietin in anaemia of

\section{Patients and methods}

Thirty five anaemic patients ( 23 female, 12 male) with classical or definite active rheumatoid arthritis according to the criteria of the American Rheumatism Association were examined. The age of the patients ranged from 39 to 80 years (median age 66). Active rheumatoid arthritis was defined by the fulfilment of at least three of the following four criteria: swelling in at least three joints; tenderness in at least six joints; an erythrocyte sedimentation rate (ESR) $\geqslant 28$ $\mathrm{mm} / \mathrm{h}$; morning stiffness of at least 45 minutes. 
Thirty of the 35 patients were treated with a disease modifying antirheumatic drug (penicillamine (10), sodium aurothiomalate (six), hydroxychloroquine sulphate (seven), and sulphasalazine (seven)). All but one were treated with a non-steroidal anti-inflammatory drug, and eight patients were treated with prednisolone systemically (5-15 mg/day). The medical treatment was not significantly different between the iron replete and the iron depleted groups.

All patients were anaemic with haemoglobin concentrations below $114 \mathrm{~g} / 1$ in women, and below $130 \mathrm{~g} / \mathrm{l}$ in men. On entry into the study no patients received iron supplementation or had received blood transfusions within the preceding six months. Patients with reticulocytosis, abnormal differential count, decreased serum folate and serum cobalamine concentrations, increased serum creatinine concentrations, or an abnormal urine sediment were excluded from the study. Patients undergoing treatment with azathioprine, methotrexate, cyclophosphamide, or dapsone were also excluded.

Laboratory investigations in all patients included haemoglobin, mean cell volume, mean cell haemoglobin concentration, reticulocyte count, leucocyte count plus differential, platelet count, serum iron, serum transferrin, ESR, C reactive protein (CRP) in serum, all according to routine practice at the hospital laboratory.

The refererence population with nonnephrogenic anaemia used for evaluation of the secretory erythropoietin response in the anaemic patients with rheumatoid arthritis were 86 patients with multiple myeloma. None of these patients had kidney disease and all showed varying degrees of anaemia.

\section{STATISTICS}

Student's $t$ test, the Mann-Whitney U test, and Spearman's rank correlation coefficient were used for statistical analysis. A significance level of $5 \%$ was selected.

\section{ASSESSMENT OF IRON STATUS}

Iron status was evaluated by bone marrow examination. Posterior iliac crest bone marrow aspirations were performed in all patients. Bone marrow was fixed in phosphate buffered saline, 4\% formaldehyde and embedded in paraffin. Serial sections were stained for iron in Perls' Prussian blue. ${ }^{10}$ The stained preparations were graded semiquantitatively for iron content according to the following criteria: $0=$ no iron; $1=$ minimal or very small amounts; $2=$ slight and patchy; $3=$ moderate and diffuse; $4=$ strong, extensive and diffuse content. Iron grades $0-1$ were regarded as indicating iron deficiency. ${ }^{11}$ The histological examination was carried out as a blind study.

Serum ferritin concentrations were analysed by a competitive radioimmunoassay (Medicinsk Lab, Copenhagen, Denmark); normal range $15-300 \mu \mathrm{g} / 1$ in men; $10-120 \mu \mathrm{g} / 1$ in women.

Patients were separated into two groups according to iron status: (1) an iron replete group defined by $(a)$ a marrow iron grade of $2-4$ and $(b)$ a serum ferritin concentration $>60$ $\mu \mathrm{g} / \mathrm{l}$. (2) An iron depleted group defined by $(a)$ a

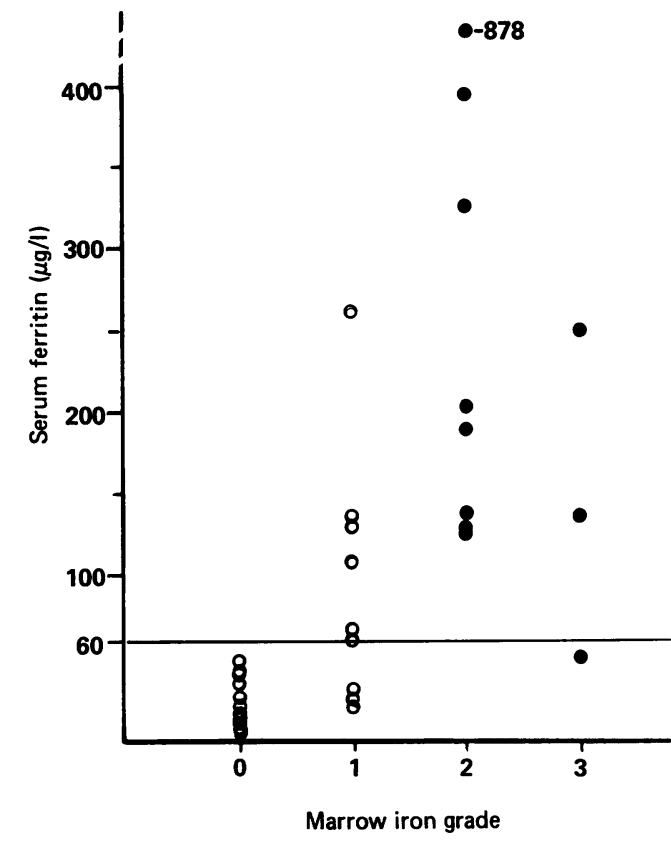

Figure 1: Serum ferritin concentrations related to different marrow iron grades in anaemic patients with rheumatoid arthritis either with depleted iron stores, marrow iron grade $0-1(\mathrm{O})$, or with adequate iron stores, marrow iron grade $2-4(\mathbf{0})$.

marrow iron grade of $0-1$ and $(b)$ a serum ferritin concentration $\leqslant 60 \mu \mathrm{g} / \mathrm{l}$ (fig 1 ).

Plasma lactoferrin concentrations were measured by a sensitive enzyme linked immunosorbent assay (ELISA); normal range $46-257 \mu \mathrm{g} / 1 .{ }^{12}$

RED CELL DISTRIBUTION WIDTH

Determination of red blood cell distribution width with establishment of erythrocyte histograms was performed on EDTA anticoagulated blood samples by a Technicon $\mathrm{Hl}(\mathrm{tm})$ automatic analysing system; normal red cell distribution width $11 \cdot 5-14 \cdot 5 \%$ (95\% centiles) (fig 2 ).

\section{SERUM ERYTHROPOIETIN MEASUREMENTS}

Concentrations of erythropoietin in patient serum samples were analysed by a competitive radioimmunoassay of human erythropoietin essentially as previously described. ${ }^{13}{ }^{14} \mathrm{~A}$ polyclonal rabbit antihuman erythropoietin antibody directed against highly purified recombinant human erythropoietin was used as the primary antibody. ${ }^{125}$ I labelled recombinant human erythropoietin (IM 219) from Amersham was used as tracer in the radioimmunoassay. The standard was the 21RP of human urinary erythropoietin (WHO). Goat antirabbit gammaglobulin (Calbiochem) was used as precipitating antibody. The normal range of the assay is approximately $15-30 \mathrm{U} / 1$.

\section{Results}

The semiquantitative estimation of stainable marrow iron and the measurement of serum ferritin concentrations divided the patients with rheumatoid arthritis into two subpopulations. In $19 / 35$ (54\%) of the patients iron stores were empty (marrow iron grade 0-1) and serum 
ferritin concentrations $\leqslant 60 \mu \mathrm{g} / \mathrm{l}$, while only $10 / 35(29 \%)$ of the patients had both adequate marrow iron stores (marrow iron grade 2-4) and a serum ferritin value $>60 \mu \mathrm{g} / \mathrm{l}$ (fig 1). Six patients, however, had to be excluded from the evaluation of iron status owing to discrepancies between marrow iron grade and the corresponding serum ferritin concentration. Serum ferritin concentrations were significantly higher in patients with adequate marrow iron (marrow iron grade 2-4) than in patients with depleted

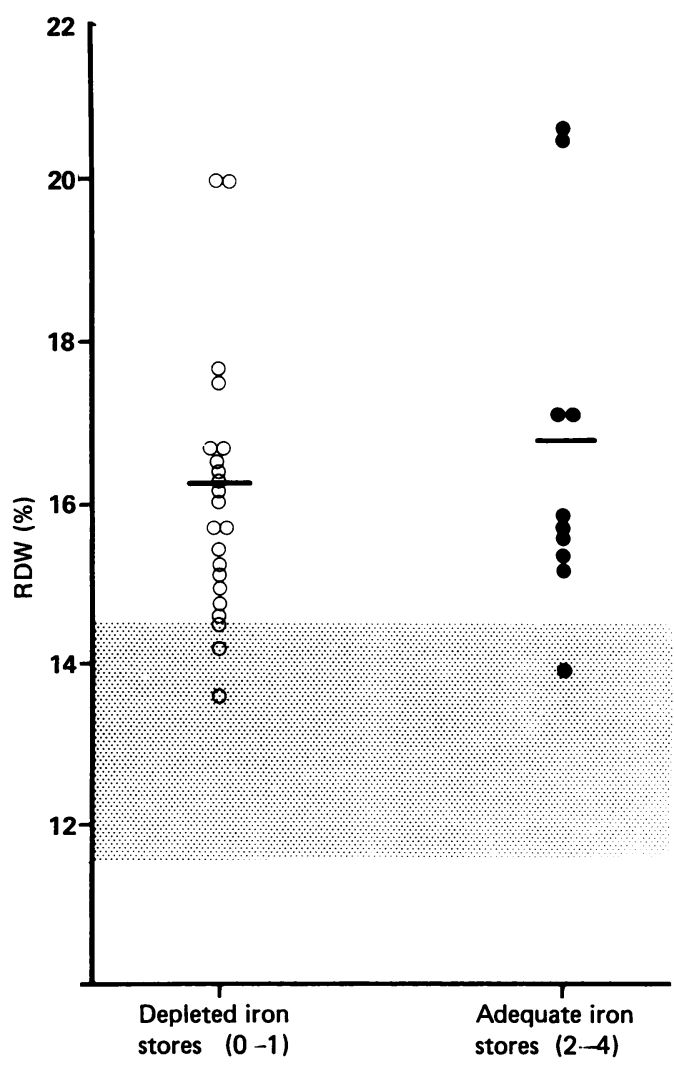

Figure 2: Red cell distribution width $(R D W)$ in the two subpopulations of anaemic patients with rheumatoid arthritis. The mean $R D W(\%)$ is significantly raised in both.

$\mathrm{O}=$ anaemic patients with iron deficiency; $\mathrm{O}=$ anaemic patients with adequate iron. The grey zone represents the normal range of $R D W(=11 \cdot 5-14 \cdot 5 \%)$. iron stores (marrow iron grade 0-1) (mean (SD) $257 \cdot 36(228 \cdot 1) \mu \mathrm{g} / \mathrm{l} v 51 \cdot 58(57 \cdot 7) \mu \mathrm{g} / \mathrm{l}$; table). Serum transferrin concentrations were significantly lower in the patients with adequate iron than in patients with iron deficiency $(23.3(3.8)$ $\mu \mathrm{mol} / \mathrm{l} v 26.9(5 \cdot 3) \mu \mathrm{mol} / \mathrm{l})$. The mean serum iron concentration $(8 \cdot 3(3.7) \mu \mathrm{mol} / \mathrm{l})$ in the total patient population was significantly depressed compared with normal, but the extent of hypoferraemia did not differ significantly in the two groups of patients. The mean concentration of plasma lactoferrin was normal, and again the two groups of patients showed no difference (table).

All patients were only moderately anaemic, and there was no significant difference in haemoglobin concentrations, packed cell volume, and reticulocyte counts between the two subpopulations of patients (table).

Serum erythropoietin concentrations were significantly raised in the anaemic patients with rheumatoid arthritis as a whole in comparison with healthy controls $(57.6(27 \cdot 3)$ U/l $v 22.5$ $(8 \cdot 5) \mathrm{U} / \mathrm{l})$, but no changes in mean serum erythropoietin titres between the two groups of patients were observed.

In the total population of patients there was a significant negative linear correlation between the haemoglobin concentration and $\log$ serum erythropoietin concentration $(r=0.529$; $p=0.0011$, Student's $t$ test) (fig 3 ). In the patients with adequate iron a significant linear inverse correlation was also found $(0.02>p>0.01$, Spearmann's correlation coefficient $=-0 \cdot 764)$. In the subpopulation of patients with iron deficiency, however, no significant linear correlation was found $(\mathrm{p}>0.02$, Student's $t$ test). The slopes of the two regression lines, though, did not vary significantly from each other ( $p>0.05$, Student's $t$ test).

In the 86 reference patients with non-nephrogenic anaemia (predominantly patients with multiple myeloma with varying degrees of anaemia), however, the slope of the regression curve $(R=0.716 ; p<0.0001$; slope -0.332$)$ was considerably steeper than that of the corresponding regression curve derived from the total

Hematological features and iron status of 35 anaemic patients with active rheumatoid arthritis. Values are given as means (SD)

\begin{tabular}{|c|c|c|c|c|c|c|}
\hline \multirow{2}{*}{$\begin{array}{l}\text { Laboratory } \\
\text { value } \\
\text { (normal range) } \\
\text { Haemoglobin (g/l) } \\
\quad(\mathrm{F} 110-160 ; M \text { M } 130-175)\end{array}$} & \multicolumn{2}{|c|}{ All patients } & \multicolumn{2}{|c|}{$\begin{array}{l}\text { Patients with } \\
\text { iron deficiency } \\
(M I G+0-I)\end{array}$} & \multicolumn{2}{|c|}{$\begin{array}{l}\text { Patients with } \\
\text { adequate iron } \\
(M I G \quad 2-4)\end{array}$} \\
\hline & $105 \cdot 5$ & $(11 \cdot 1)$ & $106 \cdot 7$ & $(10.9)$ & $103 \cdot 5$ & $(11 \cdot 9)$ \\
\hline $\begin{array}{l}\text { Packed cell volume } \\
\quad(\text { F 0.35-0.47; } 0.4-0.52)\end{array}$ & 0.34 & $(0.03)$ & 0.34 & $(0.03)$ & 0.33 & $(0.03)$ \\
\hline $\begin{array}{l}\text { Reticulocytes }(\%) \\
(0 \cdot 2-2 \cdot 0)\end{array}$ & $2 \cdot 34$ & $(1 \cdot 01)$ & $2 \cdot 46$ & $(0.99)$ & $2 \cdot 10$ & $(1 \cdot 11)$ \\
\hline $\begin{array}{r}\text { MCV† (fl) } \\
(80-110)\end{array}$ & $91 \cdot 9$ & $(6 \cdot 36)$ & $91 \cdot 5$ & $(7 \cdot 02)$ & $92 \cdot 7$ & $(5 \cdot 1)$ \\
\hline$\underset{(305-355)}{\operatorname{MCHC}}$ & 310.6 & $(15 \cdot 5)$ & $311 \cdot 1$ & $(15 \cdot 1)$ & $308 \cdot 6$ & $(17 \cdot 5)$ \\
\hline $\begin{array}{l}\text { Red cell distribution width (\%) } \\
(11.5-14 \cdot 5)\end{array}$ & $16 \cdot 31$ & $(1 \cdot 84)$ & $16 \cdot 12$ & $(1 \cdot 66)$ & $16 \cdot 67$ & $(2 \cdot 25)$ \\
\hline $\begin{array}{l}\text { Serum erythropoietin }(\mathrm{U} / \mathrm{l}) \\
(15 \cdot 0-30 \cdot 0)\end{array}$ & $57 \cdot 6$ & $(27 \cdot 3)$ & $60 \cdot 5$ & $(30 \cdot 0)$ & $47 \cdot 5$ & $(16 \cdot 5)$ \\
\hline $\begin{array}{l}\text { Serum ferritin }(\mu \mathrm{g} / \mathrm{l}) \\
\quad\left(\mathrm{F} 10-120 ; \mathrm{M}^{15-300)}\right)\end{array}$ & $116 \cdot 26$ & $(164 \cdot 18)$ & $51 \cdot 58$ & $(57 \cdot 7)$ & $257 \cdot 36$ & $(228 \cdot 1)^{\prime)}$ \\
\hline $\begin{array}{l}\text { Serum iron }(\mu \mathrm{mol} / \mathrm{l}) \\
(9 \cdot 0-35 \cdot 0)\end{array}$ & $8 \cdot 3$ & $(3.69)$ & $8 \cdot 75$ & $(3 \cdot 64)$ & $7 \cdot 33$ & $(4 \cdot 06)$ \\
\hline Serum transferrin $(\mu \mathrm{mol} / \mathrm{l})$ & 26.93 & $(5 \cdot 41)$ & $28 \cdot 8$ & $(5 \cdot 25)$ & $23 \cdot 3$ & $3 \cdot 78$ \\
\hline $\begin{array}{l}\text { Plasma lactoferrin }(\mu \mathrm{g} / \mathrm{l}) \\
(46-257)\end{array}$ & $137 \cdot 6$ & $(109 \cdot 9)$ & $128 \cdot 25$ & $(85 \cdot 71)$ & 168 & $(157 \cdot 8)$ \\
\hline
\end{tabular}

${ }^{*} \mathrm{p}<0.01 ;{ }^{* *} \mathrm{p}<0.05$.

$\dagger M I G=$ marrow iron grade; $M C V=$ mean cell volume; $M C H C=$ mean cell haemoglobin concentration 


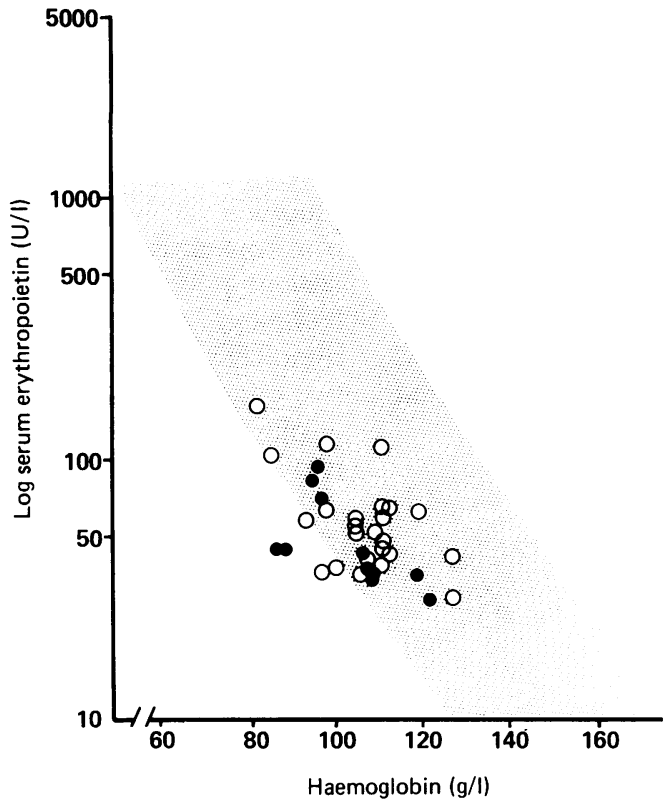

Figure 3: Corresponding haemoglobin concentrations and serum erythropoietin concentrations in anaemic patients with rheumatoid arthritis. $\mathrm{O}=$ anaemic patients with iron deficiency; $=$ anaemic patients with adequate iron. The grey zone represents patients with non-nephrogenic anaemia, predominantly anaemic patients with multiple myeloma.

population of anaemic patients with rheumatoid arthritis $(R=0.529 ; p=0.0011$; slope $=-0.133)$ (fig 3 ). The difference in the course of the slopes was significant $(\mathrm{t}=3.91 ; \mathrm{p}<0.01$, Student's $t$ test). When regression lines were calculated for the two groups including only patients with plasma haemoglobin concentrations $>80 \mathrm{~g} / \mathrm{l} \mathrm{no}$ significant difference was found $(0 \cdot 2>p>0 \cdot 1$, Student's $t$ test). The haemoglobin/log erythropoietin coordinates of almost all patients, on the other hand, fell within the range of the expected values of other non-nephrogenic anaemias (fig 3).

Both the mean ESR $(80.5(30.9) \mathrm{mm} / \mathrm{h})$ and mean serum CRP concentrations (105.8 (90) $\mathrm{mg} / \mathrm{l}$ ) were significantly higher in the iron replete patients than in the iron depleted patients (ESR $64.0(26.8) \mathrm{mm} / \mathrm{h}$; serum CRP $66 \cdot 1 \quad(52 \cdot 1) \quad \mathrm{mg} / \mathrm{l})$. The significance levels were for serum CRP $p \leqslant 0.02$ and for ESR $0.02<\mathrm{p}<0.05$ (unpaired Mann-Whitney U test).

Furthermore, in the patients with adequate iron, but not in the iron depleted patients, there was a tendency for serum erythropoietin concentrations to correlate positively both with ESR and serum CRP $\left(r_{s}=0.59 ; 0.1>p>0.05\right.$; Spearman's rank correlation coefficient). Haemoglobin concentrations in patients with adequate iron also tended to correlate inversely with ESR $\left(r_{s}=-0.79 ; 0.01<p<0.02\right.$, Spearman's rank correlation coefficient).

Both in patients with adequate iron and in the subpopulation with deficient iron the erythrocytes were found to belong to the heterogeneous, normocytic category as assessed by red cell distribution width analysis.

Although the mean red cell distribution width $(16.3(1.8) \%)$ was significantly higher in both groups of patients with rheumatoid arthritis than normal $(11 \cdot 5-14 \cdot 5 \%)$, the value for iron deficient patients $(16 \cdot 1(1 \cdot 7) \%)$ did not differ significantly from the corresponding value in iron replete patients $(16.7(2.3) \%)$; Student's $t$ test unpaired data (fig 2).

\section{Discussion}

The compensatory secretory erythropoietin response was found to be adequate for the degree of anaemia in our patients with active rheumatoid arthritis. Moreover, the release of erythropoietin was appropriate irrespective of whether the anaemia was complicated by iron deficiency or not. Even though the slope of the log erythropoietin haemoglobin curve was significantly flatter than the corresponding curve found in patients with non-nephrogenic amaenia, only limited importance is attributed to this finding. The fact that all the anaemic patients with rheumatoid arthritis had moderate anaemia only, whereas the patients with nonnephrogenic anaemia included some cases of grave anaemia with very high erythropoietin concentrations must be taken into account. Because concentrations of erythropoietin rise exponentially with decreasing haemoglobin values these severely anaemic patients exert a strong influence on the course of the log erythropoietin haemoglobin curve. In fact, when the regression line of the anaemic patients with rheumatoid arthritis was compared with the corresponding regression of the patients with multiple myeloma who had a comparable degree of anaemia (haemoglobin $>80 \mathrm{~g} / \mathrm{l}$ ), no significant difference was observed. What seems to be more essential is that the serum erythropoietin concentrations found in our patients with rheumatoid arthritis fall within the expected range for the patients with nonnephrogenic anaemia, even though they tend to cluster in the lower part of this range (fig 3 ).

In keeping with the findings of other studies 67 our data indicate that deficient secretion of erythropoietin is not involved in the pathogenesis of the anaemia associated with active rheumatoid arthritis.

In accord with the observations by Birgegaard et $a l^{7}$ we also found evidence to support the contention that serum erythropoietin concentrations tend to increase in proportion to the degree of inflammatory activity in active rheumatoid arthritis.

In a series of less convincing older investigations, which relied on an insensitive bioassay for the measurement of serum erythropoietin concentrations, it was originally claimed that serum erythropoietin was generally insufficiently low for the degree of anaemia in rheumatoid arthritis. ${ }^{15} 16$ Some recent studies, also, based on sensitive radioimmunoassay of serum erythropoietin concentrations seem to confirm the existence of a blunted secretion of erythropoietin in anaemic patients with active rheumatoid arthritis. ${ }^{45}$

The biological significance of marginally or modestly decreased serum erythropoietin concentrations which has been noted by some authors ${ }^{45}$ is not evident because 'threshold' serum erythropoietin values able to maintain 
adequate erythropoiesis still remain to be defined for different degrees of reduction in red cell mass. On the other hand, this does not rule out the possibility that the sensitivity of the erythroid stem cells to the stimulatory effect of erythropoietin might be critically lowered in anaemia of chronic disorders. The possible existence of a decreased bone marrow sensitivity to erythropoietin seems to agree well with the recently obtained clinical experience that dose requirements of recombinant human erythropoietin are radically increased in chronic haemodialysis during infectious episodes or in conjunction with surgery. ${ }^{17}$ In addition, in vitro studies have clearly shown that interleukin 1 exerts a dose dependent inhibition on erythropoietin induced formation of erythroid colonies, which can be overcome by excessive doses of recombinant human erythropoietin. ${ }^{18}$

The semiquantitative estimation of stainable iron in the bone marrow remains a valuable standard in the measurement of body iron stores. This study is the first to introduce a systematic evaluation of both stainable marrow iron and serum ferritin in the assessment of serum erythropoietin concentrations. Variations of marrow iron grade in our patients however, were found not to be associated with changes in serum erythropoietin concentrations. This dual estimation of body iron content also allowed a reappraisal of the value of serum ferritin as an indicator of complicating iron deficiency in rheumatoid arthritis. Our results confirm that a serum ferritin concentration $\leqslant 60 \mu \mathrm{g} / \mathrm{l}$, which is about five times higher than the corresponding threshold value in normal subjects, will predict iron deficiency in $80 \%$ of patients. ${ }^{19}$

Bessmann et al presented data to support the contention that the red cell distribution width is valuable in distinguishing between iron deficiency anaemia, which is associated with increased values of red cell distribution width, and anaemia of chronic disorders, in which normal values are found.$^{20}$ Our data, however, clearly contradict these original findings. In this study red cell distribution width values in patients with depleted iron stores did not significantly differ from values in the patients with rheumatoid arthritis with adequate iron stores. In both subpopulations of anaemic patients with rheumatoid arthritis red cell distribution width was significantly higher than normal. In recent studies on red cell distribution width values in patients with anaemia of chronic disorders an increased heterogeneity of erythrocyte size has also been shown. ${ }^{21}$

It has been suggested that lactoferrin is involved in the pathogenesis of anaemia of chronic disorders owing to its ability to translocate iron to intracellular ferritin in cells from the monocyte/macrophage system. ${ }^{22}$ This study does not rule out that hypothesis, but if it is correct such a mechanism does not include as a prerequisite high concentrations of plasma lactoferrin.

The technical assistance of Mrs Ulla Biørnsen is greatly appreciated. OJN was supported by Fonden til Lægevidenskabens Fremme for Kabenhavn of Frederiksberg Kommune.

1 Hansen $\mathrm{N}$ E. The anaemia of chronic disorders. A bag of unsolved problems. Scand f Haematol 1983; 31: 397-402.

unsolved problems. Scand f Haematol 1983; 31: $397-402$. 1983; 20: 61-79.

3 Cavill I, Bentley D P. Erythropoiesis in the anaemia of rheumatoid arthritis. Br F Haematol 1982; 50: 583-90.

4 Baer A N, Desypris E N, Goldwasser E. Blunted erythropoietin response to anaemia in rheumatoid arthritis. $\mathrm{Br} 7$ Haematol 1987; 66: 559-64.

5 Hochberg M C, Arnold C M, Hogans B B. Serum immunoreactive erythropoietin in rheumatoid arthritis: impaired response to anemia. Arthritis Rheum 1988; 31: 1318-21.

6 Cotes P M. Immunoreactive erythropoietin in serum. $B r f$ Haematol 1982; 50: 427-38.

7 Birgegaard G, Hällgren R, Caro J. Serum erythropoietin in rheumatoid arthritis and other inflammatory arthritides: relationship to anaemia and the effect of antiinflammatory drugs. $\mathrm{Br} \mathcal{F}$ Haematol 1987; 65: 479-83.

8 Winearls C G, Pippard M J, Downing M R. Effect of human erythropoietin derived from recombinant DNA on the anemia of patients maintained on hemodialysis. Lancet 1986; ii: $1175-8$.

9 Means R T, Olsen N J, Krantz S B. Treatment of the anemia of rheumatoid arthritis with recombinant human erythropoietin: clinical and in vitro results. Blood 1987; 70 (suppl poietin:
1): $139 \mathrm{a}$.

10 Perls $M$. Nachweis von Eisenoxyd in gewissen Pigmenten. Virchows Archiv. A, Pathological Anatomy and Histology 1867; 39: 42 .

11 Weinfeld A. Storage of iron in man. Acta Med Scand 1964; 177 (suppl 1): 427

12 Birgens H S. Lactoferrin in plasma measured by an ELISA technique: evidence that plasma lactoferrin is an indicator of neutrophil turnover and bone marrow activity in acute leukaemia. Scand f Haematol 1985; 34: 326-31.

13 Nielsen O J, Costa-Giomi P, Weinmann R. Erythropoietin- $;$ D-galactosidase. The generation, purification and use of a fusion protein. F Immunol Methods 1988; 11: 1-9.

14 Nielsen O J. Determination of human erythropoietin by radioimmunoassay. Method and clinical data. Clin Chim radioimmunoassay. Meta $1988 ; 176$ : 303-14.

15 Douglas S W, Adamson J W. The anaemia of chronic disorders. Studies of marrow regulation of iron metabolism Br F Haematol 1975; 45: 55-65.

16 Ward H P, Gordon B, Picket J C. Serum levels of erythropoietin in rheumatoid arthritis. 7 Lab Clin Med 1969; 74: 93-101.

17 Eshbach J W, Adamson J W. Recombinant human erythropoietin: implications for nephrology. Am f Kidney Dis 1988; 9: 203-9.

18 Schooley J C, Kullgren B, Allison A C. Inhibition by interleukin-1 of the action of erythropoietin on erythroid precursors and its possible role in the pathogenesis of precursors and its possible role in the pathogenesic

19 Mørk Hansen T, Hansen N E, Birgens H S. Serum ferritin and the assessment of iron deficiency in rheumatoid arthritis. Scand $\mathcal{F}$ Rheumatol 1983; 12: 353-9.

20 Bessmann J D, Ridgway Gilmer P, Gardner F H. Improved classification of anemias by MCV and RDW. Am $\mathcal{F}$ Clin Pathol 1983; 80: 322-6.

21 Baynes R D, Flax H, Bohwell T H. Red blood cell distribution width in the anemia secondary to tuberculosis. Am f Clin Pathol 1986; 85: 226-9.

22 VanSnick J L, Masson P L, Heremans J F. The involvement of lactoferrin in the hyposideremia of acute inflammation. $\mathcal{J}$ Exp Med 1974; 140: 1068-84.

23 Birgens H S, Østergaard Kristensen L, Borregaard N, et al. Lactoferrin-mediated transfer of iron to intracellular ferritin in human macrophages. European fournal of Haematology 1988; 41: 52-7. 